\title{
SHARIA LIFE INSURANCE BUSINESS AND RISK MANAGEMENT BASED ON SHARIA PRINCIPLES: REGULATORY PERSPECTIVE
}

\author{
Parmujianto \\ STAI Al-Yasini Pasuruam, Jawa Timur \\ email: Parmujianto.008@gmail.com
}

\begin{abstract}
Sharia life insurance is an agreement between two parties. One is obliged to pay a contribution or premium, and the other must ensure a full guarantee of the insurers. It should undertake the protection of a contingent or uncertain loss based on the contract. This research used a descriptive qualitative approach. It seeks to explore and understand the central phenomenon to obtain in-depth data to reveal the facts on the research object. The theoretical contribution in this study can contribute to the insights about the insurance partnership of $A S Y K I$, Inc. to increase the number of insurance participants. It is expected that people do not have doubts about sharia life insurance in a formal juridical manner related to insurance. The result of the research showed that Asuransi Shariah Keluarga Indonesia ASYKI, Inc Pasuruan Unit's performance is generally good. According to Law No.40 of 2014, its risk management is sharia-oriented. However, it does not rule out individuals who register individually. Still, ASYKI, Inc. Pasuruan Unit provides some solutions. They should register with the ASYKI partners. It opens an opportunity for the polis applicants to easily recognize and apply sharia life insurance without going through business entities or companies that act as intermediaries.
\end{abstract}

الملخص: التأمين على الحياة في الشريعة هو تأمين أو اتفاق بين طرفين يلتزم فيه أحد

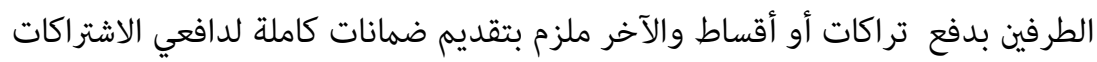

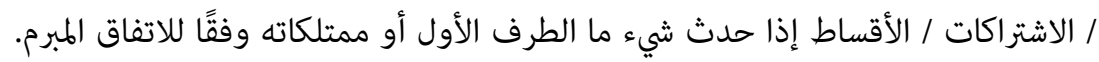

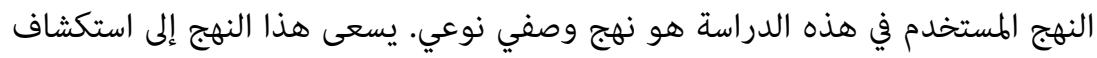

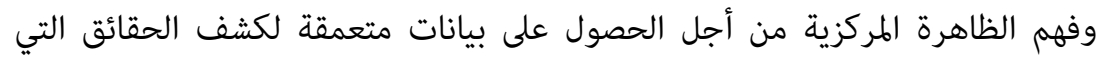


حدثت في موضوع البحث. يمكن أن تساهم المساهمات النظرية في هذه الدراسة في المعرفة

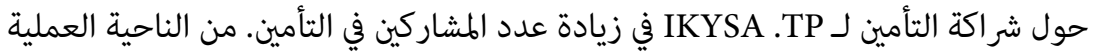

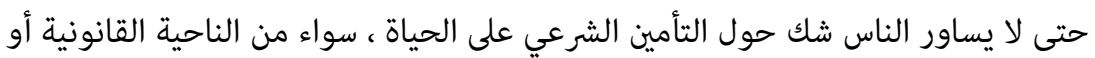

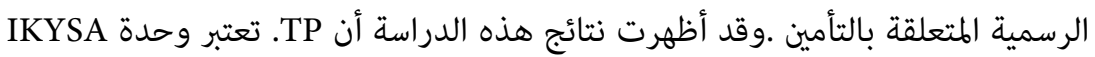
عaurusaP

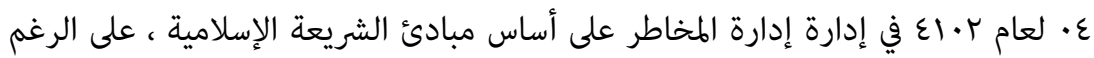

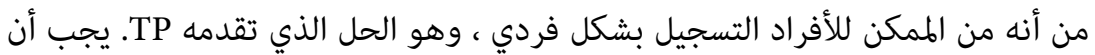

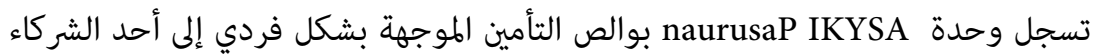
الذين يعملون مع TP. سيفتح IKYSA وفي المستقبل فرصًا لمسجلي السياسة الفردية بحيث يكون الجمهور أكثر حرية في التعرف على التأمين على الحياة وتطبيقه وفقًا للشريعة الماتِ بسهولة دون الحاجة إلى المرور عبر كيان تجاري أو شركة تعمل كوسيط.

Abstrak: Asuransi jiwa syari'ah merupakan pertanggungan atau perjanjian antara dua belah pihak yangmana pihak satu berkewajiban membayar kontribusi atau premi dan yang lainnya memiliki kewajiban memberikan jaminan sepenuhnya kepada pembayar iuran/kontribusi/premi apabila terjadi sesuatu yang menimpa pihak pertama atau barang miliknya sesuai dengan perjanjian yang sudah dibuat. Pendekatan yang digunakan dalam penelitian ini adalah pendekatan kualitatif deskriptif. Pendekatan ini berusaha mengekplorasi dan memahami gejala sentral agar mendapatkan data yang mendalam guna mengungkapkan fakta yang terjadi pada objek penelitian. Kontribusi teoritis dalam penelitian ini dapat memberikan sumbangsih ilmu pengetahuan tentang kemitraan asuransi PT. ASYKI dalam menambah jumlah peserta asuransi. Adapun secara praktis agar masyarakat tidak memiliki keraguan mengenai asuransi jiwa shariah, baik secara yuridis formal yang berhubungan dengan perasuransian. Hasil daripenelitian inibahwaPT. Asuransi Shariah KeluargaIndonesia ASYKI Unit Pasuruan secara umum dan keseluruan sudah baik dan sesuai dengan UU No.40 Tahun 2014 dalam pengelolaan manajemen resiko sudah berdasarkan prinsip shariah, meskipun tidak menutup kemungkinan ada individu yang mendaftarkan diri secara perorangan, namun solusi yang ditawarkan dari pihak PT. ASYKI Unit Pasuruan hendaknya pendaftar poli asuransi secara individu di arahkan pada salah satu mitra yang bekerja sama 
dengan PT. ASYKI dan ke depannya akan membuka peluang bagi pendaftar polis secara perorangan sehingga masyarakat lebih leluasa untuk mengenal dan menerapkan asuransi jiwa shariah dengan mudah tanpa harus melalui badan usaha atau perusahaan yang menjadi perantara.

Keywords: Islamic insurance, risk management, sharia principles, regulatory.

\section{INTRODUCTION}

The development of Islamic insurance in Indonesia has progressed rapidly due to the majority of the Muslim population, thus making the demand for Islamic insurance even higher. There are several types of insurance offered by insurance companies in Indonesia, one of which is life insurance.

Insurance is an agreement between two parties in which one party is obliged to pay a contribution or premium. The other must provide a full guarantee to the premium/contribution/premium payer if something happens to the first party or his belongings based on the agreement that has been made. The term insurance usually refers to anything that is protected. ${ }^{1}$

Sulistio Purwaningrum et al. in 2020, a study was conducted on "Determining the Growth of Assets of Sharia Life Insurance Companies in Indonesia for the 2013-2018 Period." It was said that the growth in assets of sharia life insurance companies simultaneously took advantage of investment returns, operating expenses, participant contributions, and claims. ${ }^{2}$ Ridwan Tabe et al., in their research in 2018 entitled "The Effect of Premiums on Profits in Life Insurance Companies at the Sharia Unit of Panin Dai-Ichi Life Indonesia, Inc.," explained that the premium has a significant effect on profits. ${ }^{3}$

\footnotetext{
wikipedia, "Asuransi," https, $2020<$ https://id.wikipedia.org/wiki/Asuransi>.

2 Sulistio Purwaningsih Dkk, "Determinan Pertumbuhan Aset Perusahaan Asuransi Jiwa Shariah di Indonesia Periode 2013-2018," Jurnal Ekonomi Shariah Teori dan Terapan, 7 (2020), 955-970.

3 Ridwan Tabe Dkk, "Pengaruh Premi terhadap Laba Perusahaan Asuransi Jiwa pada Unit Shariah PT. Panin Dai-Ichi Life Indonesia," Jurnal Economic and Businees of Islam, 3 (2018), 327-344.
} 
Meanwhile, Siti Maskanah researched "Implementation of Sharia Life Insurance Products for Family Economic Stability. The results show that having protection in the form of life insurance will be safe, comfortable, and investment is one of the conditions so that the economy of a family becomes stable. Sharia life insurance products are in demand by people with minimal and high incomes. ${ }^{4}$

Alfa Immanuel Wijaya, in 2019 conducted research entitled "Implementation of the Unit Link Product Life Insurance Agreement at Allianz Life, Inc. Lampung Branch." It explained that the life insurance agreement, according to the law, must be outlined in a deed called a policy. It is evidence of an insurance agreement as stated in article 225 of the Indonesian Commercial Code and regarding the formal terms of the policy as stipulated in Article 265 of the Commercial Code. According to the provisions of the article, there are four conditions for the validity of an agreement: the existence of an agreement, the existence of authority, the existence of particular objects, and the existence of lawful power. Meanwhile, the benefits of unit-linked product life insurance are considered very profitable for the insured. Some of the benefits include additional protection, premiums that do not expire, an extended coverage period, multiple benefits, ease of investment, and premium leave facilities.

According to Dedi Yulianto in his research in 2018 "Insurance Strategies in Fostering Public Interest in Al-Amin Sharia Life Insurance, Lampung Branch," said that Al-Amin Sharia Life Insurance Lampung Branch is insurance for consumer association Sharia Life Insurance from various institutions such as banking, cooperatives, BMT, then universities, and schools. The company will provide an offer in the form of protection to bank debtors who risk congestion due to death by introducing Sharia Al-Amin Financing products. ${ }^{5}$ Yona Rizkiyanda, in 2019, conducted research entitled "Risk Management Analysis on the Sharia Life Insurance System at Asuransi Jiwa Shariah Al-Amin,

4 Siti Maskanah, "Implementasi Produk Asuransi Jiwa Shariah Terhadap Kestabilan Ekonomi Keluarga,” Jurnal Tsarwah (Ekonomi dan Bisnis Islam), 1 (2017), 111-128.

5 Dedi Yulianto, "Strategi Asuransi Dalam Menumbuhkan Minat Masyarakat Pada Asuransi Jiwa Shariah Al-Amin Cabang Lampung” (Universitas Negeri Lampung, 2018), 21-22. 
Inc. Medan Branch." It found that the risks in life insurance include risks in the insurance industry as uncertainty and financial losses. ${ }^{6}$

The similarity of previous research with this research is how to take or examine the management used by a sharia life insurance company, both unit-linked products and sharia life insurance management development strategies. The gap between the previous research and this research is that the life insurance agreement must be stated in a deed or policy. The risk of raising public interest is to trust more in sharia life insurance than conventional, the uncertainty of the insurance industry, and financial loss. Nevertheless, this study discussed how a company's management system manages a life insurance product in sharia and its legal perspective according to Law No. 40 of 2014.

Therefore, someone who applies for insurance has a goal so that if something happens to him, there is a company willing to bear it. Various types of insurance offer sickness coverage, but some also offer goods, employment, and life coverage. Along with the development of the times, many institutions have established sharia-based insurance services; of course, the principles used in their management are under the principles of sharia and Islamic teachings. As explained in the QS. al-Maidah: 2.

"And please help you in doing goodness and piety and do not help in sins and transgressions. Belief in Allah; Allah is very heavy in torment ". 7

For insurance, there is also an element of mutual help between fellow humans. In this case, it is based on the commandments of Allah contained in QS al-Maidah: 2. Insurance, when viewed as sharia, is essentially a form of mutual risk-bearing activity between fellow humans; each other becomes the guarantor for the risks of the other. ${ }^{8}$

According to the DSN Fatwa. No21/DSN-MUI/X/2001. Sharia insurance (Ta'min, Takaful, or Tadhamun) is to protect and help some

6 Yona Rizkiyanda, “Analisis Mananjemen Risiko Pada Sistem Asuransi Jiwa Shariah di PT Asuransi Jiwa Shariah Al-Amin Cabang Medan” (UIN Sumatra Utara, 2019), 39-40. 2010).

Kemenag RI, Al-Qur'an dan Terjemahannya (bandung: CV. Diponegoro,

Abdullah Amin, Meraih Berkah melalui Asuransi Shariah (Jakarta: Elex Media Komputindo, 2011), 35. 
people/parties through investment in assets and/or tabbaru. It provides a pattern of returns to face certain risks through a suitable contract (agreement).

Life insurance in the Indonesian Commercial Code (KUHD) is regulated in book 1 Chapter X Article 302 to Article 308 KUHD. The life insurance based on the provisions of Article 255 of the KUHD, which contains life insurance, must be held in writing in the form of a deed called a policy. According to the provisions of article 304 of the KUHD, the life insurance policy contains some parts. They are the day the insurance is held, the name of the insured, the name of his life insured, the start and end of the event, the amount of insurance, and the insurance premium. ${ }^{9}$

The Law of the Republic of Indonesia Number 40 of 2014 concerning insurance, article 3 paragraph 6, states that "Life Insurance Business is a business that provides risk management services that provide payments to policyholders, the insured, or other entitled parties in the event the insured dies or remains alive, or other payments to the policyholder, the insured or other entitled parties at a certain time as stipulated in the agreement, the amount of which has been determined and/or is based on the results of fund management." There is also the same article in paragraph 9 which states that "Sharia Life Insurance Business is a risk management business based on Sharia Principles to help and protect one another by providing payments based on the participant's death or life, or other payments to participants or other parties entitled to the specified time as stipulated in the agreement, the amount of which has been determined and/or based on the results of fund management.

According to the article above, the primary use in life insurance is to help each other and protect each other or between siblings. In Islam, death is an accident, and death is a person's destiny. No one knows except Allah Swt. So that humans are allowed to try to prepare themselves as well as possible before that destiny comes by preparing themselves in the form of protection of the soul by prioritizing sharia compliance.

The fundamental reason for taking the theme in this research study is because, in fact, in social life, there are still many who do not know about the existence of life insurance, maybe because they do not

9 Kitab Undang-Undang Hukum Dagang (Bandung: Gramedia Press, 2013). 
know or know but are hesitant to register themselves as life insurance customers, because of this, the author would like to discuss how the Sharia Life Insurance Management system at Asuransi Shariah Keluarga Indonesia (ASYKI), Inc. Pasuruan Unit, and the Perspective of Law Number 40 of 2014 concerning Sharia Life Insurance Business in Risk Management Based on Sharia Principles. Whereas in social life, many people still do not know about life insurance, some do not know or know but are hesitant to register or participate in life insurance.

From the phenomena that occur and the research gap that appears in this study, it is clear that not every empirical incident is in accordance with the existing theory. It is confirmed by the existence of a research gap in previous studies. The various studies above show that there are differences in asset growth in the Sharia Insurance Company. However, this research is related to the sharia life insurance business based on Law no. 40 of 2014 that research gaps emerge in risk management that is oriented towards shari'ah compliance, the value of justice, and the benefit of the people. So in this study, the question arises of how sharia life insurance business management and risk management according to Islamic sharia at Asuransi Syariah Keluarga Indonesia (ASYKI), Inc. Pasuruan Unit.

The approach used in this study was qualitative. This approach seeks to explore and understand the central phenomenon to obtain in-depth data to reveal the facts on the research object. Objects in qualitative research are natural objects or settings, so this method is often referred to as naturalistic methods. Natural objects are objects that are what they are, not manipulated by the researcher. When the researcher enters the object, after being in the object and leaving the object are relatively unchanged.

Qualitative research methods are used to obtain in-depth data, data that contains meaning. Meaning is actual data; definite data is a value behind the visible data. Therefore, qualitative research does not emphasize generalizations but instead emphasizes meaning. Generalization in qualitative research is called transferability, which means that the study results have similar characteristics. ${ }^{10}$

10 Boedi Abdullah and Beni Saebani, Metode Penelitian Ekonomi Islam Muamalah (Bandung: Pustaka Setia, 2014), 64-65. 
Data analysis in this research used the qualitative descriptive method. Descriptive is trying to describe, analyze, and assess the material that focuses on the research. The data were collected from various data sources, both primary and secondary data. They were interviews, field notes, official documents, related files, and the web problems the researchers discussed. It was related to the management system analysis at Asuransi Shariah Keluarga Indonesia, Inc. of Pasuruan Unit.

\section{BASIC INSURANCE CONCEPTS}

According to law No. 2 of 1992, insurance is an agreement of two or more parties, whereby the insurer binds himself to the insured, by receiving an insurance premium, to provide compensation to the insured due to loss, damage, or loss of expected profits, or legal liability to the insured. a third party that the insured may suffer arising from an uncertain event, or to make a payment based on death or someone insured. ${ }^{11}$

Muhammad Muslehuddin, in his book Insurance and Islamic Law, adopts the meaning of insurance from the Encyclopedia Britannica. It is a supply prepared by a group of people who suffer losses to deal with not enlivened events. If the loss falls on one of them, then the burden of the loss will be distributed throughout the group. ${ }^{12}$

Since the time of the Prophet Muhammad, the Muslims have played an essential role in introducing the insurance system to the world. In the year $200 \mathrm{H}$, many Muslim entrepreneurs started pioneering the takaful system, a system of collecting funds to be used to help businessmen who are suffering from losses each other; such as when the cargo ship hits a reef and sinks, or when someone is robbed which results in the loss of part or all of his property. This term is better known as "Sharing of Risk."13

According to Doctor Jafril Khalil concerning the DSN-MUI Fatwa. Some of the contracts contained in sharia insurance are not only limited to the Tabarru and Mudharabah contracts, but there are

11 Sri Nurhayati, Akutansi Shariah di Indonesia (Jakarta: Salemba Empat, 2013), 27.

12 Tuti Astuti, Aspek Hukum Perjanjian Asurans (Yogjakarta: Medpress Digital, 2016), 42-43.

13 Abdullah Amrin, Meraih Berkah melalui Asuransi Shariah (Jakarta: Elex Media Komputindo, 2011), 105-107. 
other types of tijarah contracts such as musyarakah (partnership), wakalah (appointment of representatives/agents), wadiah (deposit contract), syirkah (association), musahamah (contribution) and others that are recognized and justified in syar'i for use in sharia insurance. ${ }^{14}$

The contract stipulated in the sharia life insurance at the beginning of receiving the premium applies two contract forms, namely the investment savings contract and the contribution contract. For investment savings contracts based on the mudharabah principle and contribution contracts applying the grant principle, the grant is made in the congregation, which has a mutually beneficial effect. The grant amount is $5 \%$ to $10 \%$ of the total premium. The remaining $95 \%$ to $90 \%$ will go into the investment savings of participants/customers.

Deferred life insurance is caused by death (death). The death resulted in the loss of income for a person or a particular family. The risks that may arise in life insurance are mainly in the "time element" because it is difficult to know when someone dies. Mental insurance is held to minimize this risk.

Nowadays, the agreement or contract between the insurer and the insured almost always uses an agreement or contract in the form of a book (policy). Standard agreements are used so that service transactions can be carried out efficiently and practically without any obstacles due to "bargaining" before closing an agreement. In a standard agreement, the clauses in the agreement have been determined unilaterally by the insurer. These clauses tend to prioritize the insurer's rights over the insured's rights and the insurer's obligations. So that now the insurance agreement will be more straightforward, and it will not take a long time. It led to the development of life insurance in the form of unit links or Link Assurance. ${ }^{15}$

Another discussion state that the life insurance agreement according to the law must be stated in a deed called a policy as evidence of an insurance agreement as contained in the Indonesian Commercial Code (KUHD) article 225 regarding the formal terms of the policy is further regulated in Article 265 of the Indonesian Commercial Code,

14 Ismail Nawawi Uha, Manajemen Perbankkan Shariah, Teori,Pengantar Praktik dan Isu-isu Kontemporer Perkembangan dan Pengembangan Industri Perbankkan Shariah (Jakarta: CV. Dwiputra Pustaka Jaya, 2014), 22-123.

15 Punky, Asuransi Jiwa Studi Tentang Pelaksanaan Link Assurance di PT. Prudential Life Surakarta (Surakarta: Universitas Muhammadiyah, 2010), 210-211. 
so that the article regulates General Provisions that must be fulfilled so that a deed can be referred to as a policy. The terms of the life insurance agreement are regulated in Article 1320 of the Indonesian Commercial Code (KUHD). According to the provisions of this article, there are four conditions for the validity of an agreement: There is an agreement, the existence of authority, the existence of particular objects, and the existence of a lawful power of attorney.

Meanwhile, the benefits of unit-linked product life insurance are considered very profitable for the insured. Some of the benefits include additional protection, premiums that do not expire, an extended coverage period, multiple benefits, ease of investment, and premium leave facilities.

Insurance can help humans in overcoming all the risk problems they face. Insurance has now increased its function to protect the insured against the risks it faces and manage public funds with unitlinked product life insurance investments. Unit-linked product life insurance is formed by entering into a risk transfer agreement. The insured party of the unit-linked product life insurance reminds himself to pay the premium. The insurer informs the prospective insured of the terms and procedures to participate in unit-linked product life insurance. Suppose the insured candidate fulfills the requirements and procedures. In that case, a legal relationship will arise, which creates the rights and obligations among the parties that must be fulfilled in the contents of the policy. ${ }^{16}$ The types of risk commonly known in the insurance business include:

First, the pure risk is the uncertainty of a loss. In other words, there is only an opportunity of loss and not an opportunity of profit. Pure risk is a risk that will provide if it does not occur; it will not cause loss but also not benefit. For example, the car you are driving might be hit. If a car is insured and then hit, the owner will suffer a loss. However, if this does not happen, the owner will neither lose nor benefit. In its operation, the insurance company is constantly faced with this kind of pure risk.

Second, investment risk is the risk associated with the occurrence of two possibilities, namely, the opportunity to experience financial loss or the opportunity to gain profit. The difference between pure risk

16 Alfa, Pelaksanaan Perjanjian Asuransi Jiwa Produk Unit Link di PT. Allianz Life (lampung: Universitas Lampung, 2019), 83. 
and investment risk is the possibility of a loss or profit. For example, in investing in stocks on the stock exchange, and so on. Stock price fluctuations can cause losses or gains.

Third, lidividual risk is a risk that affects a person's capacity or ability to obtain an advantage. The individual risk can be divided into 3 (three) types of risk. First, personal risk (personal risk), for example, the risk of a person resulting in a reduction or loss of one's capacity to benefit, which may be caused by dying young, aging, physical disabilities, and losing a job. Second, the risk of property (property risk) at this risk will be a financial loss if we have an object or property that makes the opportunity for the property to be lost, stolen, or damaged. Loss of property means financial loss. Third, liability risk is a risk that may be experienced as detrimental to other parties. If a person bears someone else's loss, he must pay it, which is a financial loss. ${ }^{17}$

\section{REGULATION OF SHARIA PRINCIPLES IN LIFE INSURANCE}

1. Law Basic Insurance

It relates to the Law of the Republic of Indonesia No.40 of 2014 concerning insurance within the scope of insurance. ${ }^{18}$ General insurance companies can only carry out: General insurance business, including health insurance business lines and personal accident insurance business lines, and reinsurance businesses for the risks of other general insurance companies.

2. Types of Akad in Shari'ah Insurance

In addition to the mudharabah contract, several forms of contract are applied in Sharia insurance. There are also wakalah, wadiah, and musyarakah contracts. The contract forms mentioned above are applied based on the situation and condition of the business activities carried out by the parties concerned. Each contract has different characteristics or conditions in its application. ${ }^{19}$

3. Law Number 40 of 2014

The explanation of life insurance in Law Number 40 of 2014 is contained in article 1 number 6 and 9, namely: "Life Insurance

17 Yona, “Analisis Mananjemen Risiko Pada Sistem Asuransi Jiwa Shariah di PT Asuransi Jiwa Shariah Al-Amin Cabang Medan" (UIN Sumatera Utara: 2019), 39-40.

$18 \mathrm{Http} / / \mathrm{www}$, "Undang-undang Asuransi no.40 tahun 2014," 2016.

19 Abdullah Amrin, Meraih Berkah, (2011), 105-107. 
Business is a business that provides risk management services that provide payments to policyholders, the insured, or other parties who are entitled in the case of the insured. The dies or remains alive, or other payment to the policyholder, the insured or other entitled parties at a certain time as stipulated in the agreement, the amount of which has been determined and/or is based on the results of fund management".

"Sharia Life Insurance Business is a risk management business based on Sharia Principles to help and protect each other by providing payments based on the death or life of the participant, or other payments to participants or other parties who are entitled at a certain time as regulated in the agreement, the amount of which has been determined and/or based on the results of fund management." 20

It has been explained in the Code of Commercial Law Chapter $\mathrm{X}$ concerning "Insurance or coverage against fire hazards, against hazards that threaten agricultural products that have not been harvested, and about life insurance" in this case, in particular, life insurance is contained in article 302 "A person's soul can be suspended for the needs of an interested person, either for life or for a time specified in the agreement." And also continued in article 303, "Those concerned can provide coverage, even outside the knowledge or permission of the person whose soul is insured." The terms of the policy that must be fulfilled are also explained in the Commercial Code Article 304 "The policy contains: the result of the provision of the insurance, the name of the insured, the name of the person whose life is insured, the time the danger for the insurer starts and ends, the amount of money insured and insurance premiums."

Article 306 states that "If the person whose life was insured has passed away at the time of the provision of insurance, the agreement is terminated, even though the insured cannot know about the death unless otherwise required." Moreover, Article 307 explains that "If the person who is insured for his life has committed suicide or is sentenced to death, his insurance will be annulled." ${ }^{21}$

${ }^{20}$ Https://www.ojk.go.id/Files/201506/1UU402014, "Perasuransian,” 2020.

${ }^{21}$ Gramedia, Kitab Undang-Undang Hukum Dagang (Jakarta: Gramedia Perss, 2013). 


\section{RISK MANAGEMENT IN THE SHARIA LIFE INSURANCE BUSINESS}

Overview of The Pasuruan Unit of the Pasuruan Family Syari'ah Insurance, Inc. was founded by activists and practitioners of Islamic Economics and Microfinance. They were concerned about building independence and developing the community's economic welfare, especially families from the middle to lower economic circles or lowincome people through Sharia Microfinance Institutions (LKMS) and Sharia Insurance. Asuransi Shariah Keluarga Indonesia, Inc. has a background that humans in their lives cannot be spared from calamities. Still, as social beings, when a disaster occurs, they are obliged to help and help one another. Sharia insurance has the primary function as an operator in sharing risks between participants or policyholders if a disaster occurs. The basic concept of Sharia Insurance is to help you all in Kindness and Taqwa. This principle makes insurance participants a large family that helps and helps each other. Therefore, Asuransi Shariah Keluarga Indonesia, Inc. is a part of ta'awun and sharing blessings with the ummah. Asuransi Shariah Keluarga Indonesia, Inc. also has the concept and philosophy of ta 'awun, where the concept of ta'awun in the Qur'an has been explained. Humans as individual beings as well as social beings are a unity that cannot be separated. They must realize that their new life has meaning if humans are involved in social relationships. It involves interactions based on an attitude of help among pluralistic communities. In other words, without other people or living in society, a person is meaningless and does nothing. When humans maintain life and pursue a better life, someone can't work alone without the help and assistance of others. Therefore, Islam recommends that its adherents have an attitude of mutual help and assistance in living their lives. This attitude will work well if there is communication between them or they understand this because human interests are always related to other humans. ${ }^{22}$

In the al-Qur'an, Allah Swt. has ordered Muslims to continuously unite and help each other for the sake of the strength and glory of Muslims. If this happens, Muslims will respect, be liked, and respect other groups outside of Islam. Allah Swt. has confirmed this in QS. alMaidah: 2, which reads as follows: "And please help you in goodness and piety, and do not help you in committing sins and transgressions.

${ }^{22}$ Ahmad Durri, "Interview" Pasuruan, 2020. 
And fear Allah indeed Allah is very severe in torment '. By conveying the above verse, it can be understood that helping each other who is kind is an effort to increase piety to Allah Allah Swt. This attitude not only exists in material issues but also: in non-material issues, such as people experiencing worries and troubles. In this context, the help we can give is help that is non-material in nature. What is meant by the side is to provide advice and motivation to cheer or cheer him up. As a result, the worries and troubles he experiences will be replaced with joy.

But in that verse, the help referred to is help that is non-material in nature. In the author's view, help in this form can be termed da'wah. Namely, help by inviting people to do good or according to the terms of the verse is al-birr and al-taqwa. From that verse, it can be said that the doer or person who can help is not limited to certain people, especially to help that is non-material in nature. Except for material help, only people who have material can do it. For example, a wealthy person helps his poor brother and so on. In people's lives (in Indonesia), this attitude has become a national culture known as "mutual cooperation." This culture has been practiced from generation to generation, from the ancestors of the Indonesian nation to the generations of this century. But the form of assistance varies according to the abilities and conditions they face. In the city, for example, the assistance or assistance provided is more of material nature. Meanwhile, for rural communities, the assistance or assistance provided is more of a nonmaterial nature in the form of labor or the like. Therefore, habits like that should be preserved continuously whenever and wherever we are. It is based on the teachings of Islam, which always recommends adherents to help each other and help each other, especially fellow Muslims. There will be solid unity and unity and a close brotherhood among humankind. Allah Swt. will lower His help as long as a servant helps His brother. The Prophet confirmed it. In his words, as follows: "From Abi Hurairah that the Messenger of Allah has said:" Allah Swt. will help a servant as long as I help his brother" (Narrated by Muslim). Based on the hadith, it can be said that a human being must adorn himself with an attitude of help. If every human being owns this, then Allah Swt. will help and protect and be with him. 


\section{Background and Principles}

Background and Principles of Asuransi Shariah Keluarga Indonesia, Inc. Humans in their lives cannot be avoided from calamities. Still, as social beings, when a disaster occurs, they are obliged to help and help one another. Sharia insurance has the primary function as an operator in sharing risks between participants or policyholders if a disaster occurs. The basic concept of Sharia Insurance is to help you all in Kindness and Taqwa. This principle makes insurance participants a large family that helps and helps each other. Therefore, Asuransi Shariah Keluarga Indonesia, Inc. is a part of tawun and sharing blessings with the ummah. Asuransi Shariah Keluarga Indonesia, Inc. also has the concept and philosophy of ta'awun, where the concept of ta'awun in the Qur'an has been explained. Humans as individual beings as well as social beings are a unity that cannot be separated. They must realize that their new life has meaning if humans are involved in social relationships or interactions based on help among pluralistic communities. In other words, without other people or living in society, a person is meaningless and does nothing. When humans maintain life and pursue a better life, someone can't work alone without the help and assistance of others. Therefore, Islam recommends that its adherents have an attitude of mutual help and assistance in living their lives. This attitude will work well if there is communication between them or they understand this because human interests are always related to other humans. In the Quran, Allah swt. has ordered Muslims to continuously unite and help each other for the sake of the strength and glory of Muslims. If this happens, Muslims will respect, be liked, and respect other groups outside of Islam.

\section{Vision and Mission}

Vision and Mission of Asuransi Shariah Keluarga Indonesia, Inc.'s vision are to be a Pioneer of Micro Sharia Life Insurance, the Pride of the Ummat Mission: To Provide Comprehensive Micro Sharia Life Insurance Services to Provide Added Value for Participants, Partners, and Shareholders. Company Legality Deed of Establishment No. 11 December 11, 2014, Notary H. Syarif S. Tanudjaya, S.H Document Endorsement Number: AHU-41722.40.10.2014 Dated December 29, 2014, Operational Permit from OJK. Number: KEP-124 / D.05 / 2015 Dated 30 November 2015/18 Shafar 1437 H NPWP No.71,835,697.5- 
061,000 Deed of Appointment No. 02,9 May 2018 Notary Arminawan, S.H30 4.2. Based on the observations and interviews, researchers found several findings related to the formulation of the problem, namely related to how the Islamic life insurance management system at Asuransi Shariah Keluarga Indonesia, Inc. Pasuruan Unit. Mr. Ahmad Durri, as the Office Staff of Asuransi Shariah Keluarga Indonesia, Inc. Pasuruan Unit, said that ASYKI is only a representative office, all the systems used are based on the head office in Bogor. They only serve corporations such as schools, cooperatives, banks. , Institutions, and Pesantren. It was only in 2016 that an insurance brokerage established ASYKI in collaboration with BMT Sidogiri. ASYKI does not open a representative branch, only the Marketing Unit". ${ }^{23}$

Asuransi Shariah Keluarga Indonesia, Inc. has several Islamic life insurance products, namely: a. The Mu'awanah Sakinah program is shown to provide a means for families to help each other ( $t a$ ' $a w u)$ and protect (takafuli) among family members through the formation of a fund pool (tabarru fund) which is managed according to sharia principles to face risk in the form of compensation. Sharia micro life insurance for all family members has terms and conditions. First, the $M u$ 'awanah Sakinah program agreement uses the tabarru 'aqad and wakalah bi al-ujrah. Tabarru 'contract is a grant agreement giving funds from participants to the tabarru fund to help. wakalah bi al-ujrah 'aqad is a contract between participants collectively or individually with the management (Insurance Company) with a commercial purpose that gives power to the manager according to the power or authority is given, with a reward in the form of ujrah. The second contribution, in Asuransi Shariah Keluarga Indonesia, Inc. is IDR 100,000 per year. Third, the death benefit for each family member in the amount of IDR 2,500,000 died due to illness. Valid for a 30 day waiting period (a time in which there is no right to apply for $\mathrm{Mu}$ 'Cloudah compensation). Fourth, the insurance is valid for one year from the date of successful activation of the Mu'Cloudah Sakinah card. Fifth, membership requirements: a. physically and mentally healthy; b. minimum age one year and maximum 69 years; c. family members are spouses and children registered on the family card; $d$. maximum child age is 25 years and not married; e. Mu'Cloudah Sakinah is valid for a minimum of 90 days from the issuance of the family card; f. your

${ }^{23}$ Durri. 
registration card number is the participant number; g. the Mu'Cloudah Sakinah Card is proof of participation; h. one card is valid for one family. Sixth, participation data: a. name of family head: b. family card number: c. number of family members. Seventh, owe to apply for compensation: 1. participants or compensation recipients must report the incident (death in the world) through, a. Service offices, b. Office of PT Asuransi Shariah Keluarga Indonesia, c. Via SMS; 2. Send complete compensation documents. Eighth, compensation claim documents: a. copy of "Mu "Cloud Sakinah" card; b. copy of participant Indonesian identity card and family card; c. Submission of compensation from family members; $d$. death certificate from the hospital if you die in the hospital; e. death certificate from the village office; f. a letter from the police if you die in an accident. Ninth, the compensation exemption is not given if a family member: a. suicide or sentenced to death by a court; $b$. as a result of actions against the law or being involved in fights, brawls, or mass riots; c. epidemic or natural disaster $\mathrm{d}$. misuse of alcohol, illegal drugs, or other addictive substances; e. sexual relationship diseases, AIDS, HIV, ACR, and all its consequences b. Mu'awanah Virtue of Group of Students The terms and conditions of the general mu'Cloudah the goodness of a group of students are the same as mu'Cloudah Sakinah, which makes the difference including the special provisions including 1. Insurance participants: a. student/santri aged three years to 25 years; b. teachers/ staff aged 18 to 65 years. 2. Special provisions: a. the insurance period is a minimum of 1 year according to the date stated on the participant card: $b$. for risks caused by disease (not accident), a waiting period of 7 days is valid from the insurance start date stated on the participant's card.

The procedure that runs in the ongoing registration at Asuransi Shariah Keluarga Indonesia Inc., according to Ahmad Durri as the Pasuruan Unit Branch Office Staff is: "The contract that we use is wakalah bi al-ujrah, we will use mu 'cloud, the customer will represent if the customer has a disaster we will immediately help him, the risk to one of the customers for financing can be directly transferred, and the source of the money. Members hand over money to ASYKI using a tabarru contract. "The money is divided by 2 , and the first is tabarru". 
The second is given to the company or using the ujrah contract, and the distribution is $50 \%$ ujrah, $50 \%$ tabarru ". 24

The interview results show that the company only accepts insurance policy registration through the company. The risk management model in sharia life insurance has shared financial risk among participants. Meanwhile, the insurance company only acts as a regulator of the pooling of funds mandate. The transactions used are based on the tabarru' and the tijari contract. The tijari contract itself includes mudharabah, musyarakah, wakalah bi al-ujrah. All of these contracts are free from the elements of usury (interest money), maisir (gambling), gharar (fraud), and zhulman (persecution), which are expressly prohibited in Islamic law. As for Ahmad Durri from Sidogiri said: "That policy registration only occurs in stock mapping, customer financing which we usually call insurance brokers, so that in 2016 the insurance broker established ASYKI Unit Pasuruan and partnered with BMT Sidogiri”. Thus, ASYKI, Inc. Unit of Pasuruan implements a management system through adjustments to the system located at the Bogor head office. According to Law No. 40 of 2014, the sharia life insurance business is viewed from the perspective of the contract used. The practice of ASYKI, Inc. in the field is in accordance with sharia principles. It has a legal identity and legality according to state law. Through the management system that corporation has implemented. ASYKI Unit Pasuruan can be seen in handling sharia life insurance based on sharia principles and monitoring from the initial identification process to the final risk control stage.

\section{CONCLUSION}

Based on the results of this study, it can be concluded that the Indonesian Family Sharia Insurance ASYKI, Inc. Pasuruan Unit is generally well-performed. Based on Law No.40 of 2014 in risk management is based on sharia principles. However, it does not rule out individuals who register individually. Still, the solution ASYKI, Inc. Unit Pasuruan should individual poly insurance applicants be directed to one of the partners of ASYKI, Inc. It will open up opportunities for individual policy registrants to be freer to recognize and apply sharia life insurance. They can do it easily without going through an intermediary business entity or company.

24 Durri. 


\section{REFERENCES}

Amrin, Abdullah. Meraih Berkah melalui Asuransi Shariah. Jakarta : Elex Media Komputindo. 2011

Amrin, Abdullah. Strategi Menjual Asuransi Shariah. Jakarta: PT. Elex Media, Kompotindo. 2012

Ahmad Durri. Staf Kantor Cabang, PT Asuransi Shariah Keluarga Indonesia ASYKI Unit Pasuruan, wawancara pribadi, Pasuruan, 2020 .

Al-Bukhari. Shahih al-bukhari, Juz 3 Lebanon: Dar al-fikr, 1981.

Antonio, Muhammad Syafi'i. Asuransi dalam Perspekif Islam. Jakarta: Syarikat Takaful Indonesia, 1994.

Astuti Tuti. Aspek Hukum Perjanjian Asuransi. Yogjakarta: Medpress Digital, 2016.

Boedi Abdullah dan Beni Saebani. Metode Penelitian Ekonomi Islam Muamalah. Bandung: Pustaka Setia, 2014.

Dewan Asuransi Indonesia (DAI). Undang-undang RI No. 02 tahun 1992 dan Peraturan Pelaksanaan tentang Usaha Peransuransian, 2003.

Nofriansyah. Deny. Penelitian Kualitatif: Analisis kinerja lembaga pemberdayaan masyarakat kelurahan, Yogyakarta: Deepublish, 2003.

Dedi, Tontowi. "Strategi Menumbuhkan Minat Masyarakat Pada Asuransi Jiwa Syari'ah", Jurnal Ilmu Dakwah dan Pembangunan. (Vol. XIV No.1), 2019.

Dinna, Lucky. "Strategi Meningkatkan Eksistensi Asuransi Syari'ah Di Indonesia". Jurnal Maneksi, ( Vol.8 No.1), Juni 2019.

Immanuel Wijaya, Alfa. Pelaksanaan Perjanjian Asuransi Jiwa Produk Unit Link di PT. Allianz Life Cabang Lampung. Lampung: Universitas Lampung, 2019.

Maskanah, Siti. "Implementasi Produk Asuransi Jiwa Shariah Terhadap Kestabilan Ekonomi Keluarga". Jurnal Tsarwah (Ekonomi dan Bisnis Islam), Vol.1 No. 2. 2016. 
Nawawi Uha, Ismail. Manajemen Perbankkan Shariah, Teori,Pengantar Praktik dan Isu-isu Kontemporer Perkembangan dan Pengembangan Industri Perbankkan Shariah. Jakarta: CV. Dwiputra Pustaka Jaya, 2014.

Nurhayati, Sri. Akutansi Shariah di Indonesia. Jakarta: Salemba Empat, 2013.

Rizkiyanda, Yona. Analisis Mananjemen Risiko Pada Sistem Asuransi Jiwa Shariah di PT Asuransi Jiwa Shariah Al-Amin Cabang Medan. Sumatra: UIN Sumatra Utara, 2019.

Sula, Muhammad Syakir. Asuransi Syari'ah: Life and General. Jakarta: Gema Insan Press, 2004.

Sulistio Purwaningsih, Sulistio dkk. "Determinan Pertumbuhan Aset Perusahaan Asuransi Jiwa Shariah di Indonesia Periode 20132018”. Jurnal Ekonomi Shariah Teori dan Terapan, Vol.7 No, 5 Universitas Airlangga, Mei 2020.

S. Aminah dan Roikhan. Pengantar Metode Penelitian Kualitatif Ilmu Politik, Jakarta Timur: PT. Kencana, 2019.

Tabe, Ridwan dkk. "Pengaruh Premi terhadap Laba Perusahaan Asuransi Jiwa pada Unit Shariah PT. Panin Dai-Ichi Life Indonesia". Jurnal Economic and Businees of Islam, Vol. 3 No. 2. IAIN Manado, 2018.

Yulianto, Dedi, Strategi Asuransi Dalam Menumbuhkan Minat Masyarakat Pada Asuransi Jiwa Shariah Al-Amin Cabang Lampung. Lampung: Universitas Negeri Lampung, 2018.

Yurike dan Noven. "Perbedaan Efisiensi Perusahaan Asuransi Jiwa Syari'ah Dan Kovensional di Indonesia Dengan Metode Data Envelopment Analysis (DEA)". Jurnal Ekonomi Syari'ah Teori dan Terapan, Vol.4 No. 8 Agustus 2017. 